\title{
Mineral Materials as a Neutralizing Agent Used on Soil Contaminated with Copper
}

\author{
Andrzej Cezary Żołnowski ${ }^{1}{ }^{(}$, Mirosław Wyszkowski $^{1, *}{ }^{(\mathbb{C}}$, Elżbieta Rolka $^{1}{ }^{(}$and Marta Sawicka ${ }^{2}$ \\ 1 Department of Agricultural and Environmental Chemistry, University of Warmia and Mazury in Olsztyn, \\ Łódzki 4 Sq., 10-721 Olsztyn, Poland; andrzej.zolnowski@uwm.edu.pl (A.C.Ż.); \\ elzbieta.rolka@uwm.edu.pl (E.R.) \\ 2 Regional Inspectorate for Environmental Protection in Bialystok, Branch Office in Suwałki, ul. Piaskowa 5, \\ 16-400 Suwałki, Poland; marsa_90@o2.pl \\ * Correspondence: miroslaw.wyszkowski@uwm.edu.pl
}

Citation: Żołnowski, A.C.;

Wyszkowski, M.; Rolka, E.; Sawicka,

M. Mineral Materials as a

Neutralizing Agent Used on Soil Contaminated with Copper. Materials 2021, 14, 6830. https://doi.org/ $10.3390 /$ ma14226830

Academic Editor:

Pedro Maireles-Torres

Received: 6 October 2021

Accepted: 9 November 2021

Published: 12 November 2021

Publisher's Note: MDPI stays neutral with regard to jurisdictional claims in published maps and institutional affiliations.

Copyright: (c) 2021 by the authors. Licensee MDPI, Basel, Switzerland. This article is an open access article distributed under the terms and conditions of the Creative Commons Attribution (CC BY) license (https:// creativecommons.org/licenses/by/ $4.0 /)$.

\begin{abstract}
The aim of the investigation was to evaluate the response of plants, using black mustard (Brassica nigra L. Koch) as a model plant, to soil contamination with copper (0, 200, 400, $600 \mathrm{mg} \mathrm{Cu} \mathrm{kg}^{-1}$ of soil), and to determine the effectiveness of the $\mathrm{Cu}$ immobilization with mineral neutralizing materials, such as lime, clay and zeolite. The plant yield depended on soil contamination and mineral amendments. In the series without neutralizing materials, the level of $600 \mathrm{mg}$ $\mathrm{Cu} \mathrm{kg}^{-1}$ reduced the yield and increased leaf greenness. Lime alleviated the toxicity of $\mathrm{Cu}$ in objects with $200 \mathrm{mg} \mathrm{Cu} \mathrm{kg}^{-1}$. Zeolite slightly mitigated the harmful effects of $\mathrm{Cu}$ at the level of 400 and $600 \mathrm{mg} \mathrm{kg}^{-1}$. Zeolite lowered the SPAD index. In the chemical composition of plants, the content of $\mathrm{Cu}, \mathrm{K}, \mathrm{Mg}$, $\mathrm{Na}$ and $\mathrm{Ca}$ in plants increased to $400 \mathrm{mg} \mathrm{Cu} \mathrm{kg}^{-1}$, while the content of $\mathrm{P}$ decreased to $600 \mathrm{mg} \mathrm{Cu} \mathrm{kg}^{-1}$. Among the materials, lime reduced the $\mathrm{Cu}$ accumulation in plants the most, followed by clay. $\mathrm{Cu}$ narrowed the majority of ratios and widened the Ca:P and K:Ca ratios in plants. The applied mineral materials, except lime, did not significantly affect the formation of these indicators.
\end{abstract}

Keywords: copper; lime; clay; zeolite; phytotoxicity

\section{Introduction}

The development of civilization is inextricably linked with environmental pollution. Dangerous factors of anthropogenic origin are involved in processes that intensify the migration of metals to the edaphotope, which contributes to the reduction of vegetation (devegetation) and water depletion (dehumidification) and is destructive to the agrophysical, physicochemical and biological properties of soils, providing them with toxic properties [1-3]. These transformations arise mainly from the deposition of heavy metals caused by the emissions of metal-bearing dust, liquid and solid industrial and municipal waste, agricultural fertilizers and plant protection products, and motor traffic flow through roads and streets [4-12]. Any metal (metalloid) can be considered an impurity if it is present where it is not desired or in a form or concentration that causes harmful effects to humans or the environment [13]. Metals are accumulated by soils to levels that become dangerous for higher plants and for soil microflora and microfauna [14].

Soil contamination with heavy metals occurs locally and mainly concerns industrialized areas. However, in some regions, in the vicinity of emission sources, soils show a significant degree of pollution $[15,16]$. The average $\mathrm{Cu}$ content in soils in the world is $38.9 \mathrm{mg} \mathrm{Cu} \mathrm{kg}^{-1} \mathrm{DM}$ [17]. In the vicinity of metallurgical plants, e.g., the Głogów Copper Smelter (Poland), the average concentration of $\mathrm{Cu}$, depending on the depth of sampling, ranges from 2160 to $3230 \mathrm{mg} \mathrm{Cu} \mathrm{kg}^{-1}$ [18]. Globally, soil contamination in the vicinity of smelters has reached 510-9700 mg Cu kg-1 (Sudbury, ON, Canada), 1400-3700 mg Cu kg DM. (Coniston, ON, Canada) and 11600-14200 mg Cu kg-1 (Lubumbashi, DR-Congo) [19]. 
Moreover, soil contamination with copper may result from the unskillful and unbalanced application of pesticides [20-22]. An example may be the Bordeaux mixture, a fungicide based on copper compounds used until the end of the 19th century $\left(\mathrm{CuSO}_{4}+\mathrm{Ca}(\mathrm{OH})_{2}\right)$, and such forms of copper as $\mathrm{Cu}_{2} \mathrm{O}, \mathrm{Cu}(\mathrm{OH})_{2}, \mathrm{Cu}(\mathrm{OH})_{2} \cdot \mathrm{CuCl}_{2}, \mathrm{CuSO}_{4} \cdot 3 \mathrm{Cu}(\mathrm{OH})_{2}$, used in viticulture, which led to the severe accumulation of $\mathrm{Cu}$ in soils of vineyards in France, Brazil, Croatia, and Spain. Cu concentrations in the $0-20 \mathrm{~cm}$ layer currently range from 332 to $560 \mathrm{mg} \mathrm{Cu} \mathrm{kg}^{-1}$ soil $[21,22]$. Copper fungicides are also used in the protection of other agricultural plants [23,24]. The copper content in a 16-year-old Brazilian cocoa field was $993 \mathrm{mg} \mathrm{Cu} \mathrm{kg}{ }^{-1}$, which is 50 times greater than in a non-cocoa field. Copper contents in soils of British apple orchard soils have even reached $1500 \mathrm{mg} \mathrm{Cu} \mathrm{kg}^{-1}$ [25].

Copper is not biodegradable [26], and in the soil can be dissolved, chelated, adsorbed by humus, bound by soil minerals, taken up and bound by soil microorganisms or higher organisms, and precipitated in the form of insoluble mineral compounds. The durability of these bonds depends on the soil $\mathrm{pH}$, amount and type of minerals, redox potential, sorption capacity and organic matter content $[7,27]$. A method that allows reduction of the harmfulness of heavy metals is the addition of neutralizing materials to the soil [3,28-30] so as to bind metals in insoluble metal-mineral or organo-metallic forms, which-under favorable conditions-may remain in the soil in harmless forms for a long period [9,31]. The most common neutralizing materials are zeolites, bentonite, clay, lime, and also organic materials, like compost, tree bark, farmyard manure and peat $[3,23,30]$. Until recently, the methods of heavy metal immobilization have been the only available and feasible form of reclamation of contaminated soils, allowing the restoration of biological life and plant cover in degraded areas [29,32]. High concentrations of heavy metals in soil result in higher than natural concentrations in plants, which may result in an increased flow of metals to further links in the trophic chain [12,33], where they may accumulate and their harmful effects may be long-term. The excess of copper in the soil changes its properties [3] and thus modifies the chemical composition of plants, which results in a change in the ionic ratios between the elements. Too wide or too narrow ratios are very unfavorable in the case of forage plants [34-36]. Copper is an element whose deficiency is unfavorable for plants, but its excess may have a morphological, physiological, biochemical and molecular phytotoxic effect [20]. The excess of $\mathrm{Cu}$ interferes with various metabolic processes, which results in the disturbance of plant growth and development $[20,33]$. Losses caused by $\mathrm{Cu}$ in the growth and yield of food crops are much higher than the sum of other causes threatening food safety. Since soil contamination with $\mathrm{Cu}$ can also affect agricultural land, it is important to conduct research aimed at this complex problem, which has not been fully clarified [20].

Therefore, a research hypothesis was formulated that mineral materials used on $\mathrm{Cu}$ contaminated sites can reduce the toxicity of copper to plants. This action would improve the yield and change the chemical composition of the mass obtained with the simultaneous diversification of the ionic ratios vs. the null hypothesis that there was no such interaction.

The aim of the investigation was to evaluate the response of plants, using black mustard (Brassica nigra L. Koch) as a model plant, to the soil contaminated with Cu and to determine the effectiveness of the immobilization of this metal through the use of mineral neutralizing materials, such as lime, clay and zeolite.

\section{Materials and Methods}

\subsection{Experimental Design}

The pot experiment was set up in a greenhouse of the University of Warmia and Mazury in Olsztyn (Poland), according to the randomized block method. The experimental factors were (1) increasing soil contamination with copper: 0, 200, 400 and $600 \mathrm{mg}$ $\mathrm{Cu} \mathrm{kg}^{-1}$ soil; (2) using neutralizing materials (NMs): agricultural lime $\left(98.66 \% \mathrm{CaCO}_{3}\right)$ (Polcalc, Łódź, Poland) in a dose corresponding to $1 \mathrm{HAC}$, i.e., $1.06 \mathrm{~g} \mathrm{CaCO}_{3} \mathrm{~kg} \mathrm{soil}^{-1}$,

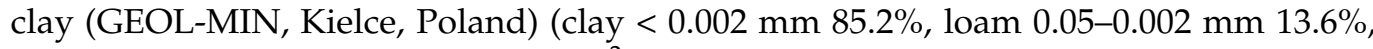
sand $0.05-2.0 \mathrm{~mm} \mathrm{1.2 \% ,} \mathrm{d}=2.73 \mathrm{~g} \mathrm{~cm}^{-3}$ ) and natural zeolite 1.0-2.5 mm (Subio Eko, Sos- 
nowiec, Poland). A Cu stock solution $\left(100 \mathrm{mg} \mathrm{Cu} \mathrm{cm}^{-3}\right)$ was prepared by dissolving $392.9 \mathrm{~g}$ of $\mathrm{CuSO}_{4} \cdot 5 \mathrm{H}_{2} \mathrm{O}$ (copper sulfate, pentahydrate) in $1000 \mathrm{~cm}^{3}\left(1 \mathrm{dm}^{3}\right)$ of deionized water. The soil in each pot was artificially enriched with the increased concentration of $\mathrm{Cu}$ by adding $16,32,48 \mathrm{~cm}^{3}$ of the $\mathrm{Cu} \mathrm{pot}^{-1}$ stock solution. Each object along with the control (without enrichment) was carried out in triplicate. Clay and zeolite were applied at a dose of $3 \%$ of the weight of the soil in a pot, i.e., $30 \mathrm{~g} \mathrm{~kg}$ of soil ${ }^{-1}$. Before starting the experiment, NPK fertilization was applied: $2.17 \mathrm{~g} \mathrm{~N}-\mathrm{CO}\left(\mathrm{NH}_{2}\right)_{2}, 0.6 \mathrm{~g} \mathrm{P}-\mathrm{KH}_{2} \mathrm{PO}_{4}, 1.25 \mathrm{~g} \mathrm{~K}-\mathrm{KH}_{2} \mathrm{PO}_{4}$ $(0.75 \mathrm{~g} \mathrm{~K})$ and $\mathrm{K}_{2} \mathrm{SO}_{4}(0.5 \mathrm{~g} \mathrm{~K}), 0.18 \mathrm{~g} \mathrm{Mg}-\mathrm{MgSO}_{4}$ and $0.25 \mathrm{mg} \mathrm{B}-\mathrm{H}_{3} \mathrm{BO}_{3}$ pot $^{-1}$. Proper brown soil used in the experiment was taken from the Ap level from a field at the Experimental Station in Tomaszkowo located near Olsztyn $\left(53^{\circ} 42^{\prime} 35^{\prime \prime} \mathrm{N}, 20^{\circ} 26^{\prime} 01^{\prime \prime} \mathrm{E}\right)$. The particle size distribution of the soil was $75.1 \%$ sand, $24.3 \%$ silt and $0.6 \%$ clay. The soil texture (according to the USDA) was classified as loamy sand. The basic properties of the soil are presented in Table 1.

Table 1. Selected physicochemical properties of soil used in experiment.

\begin{tabular}{|c|c|c|c|c|c|c|c|c|c|c|c|}
\hline Soil Type & $\begin{array}{l}\bar{v} \\
\underline{v} \\
\underline{2}\end{array}$ & 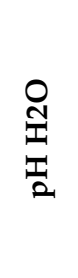 & 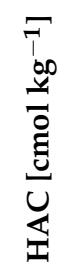 & 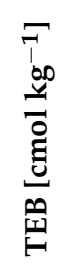 & 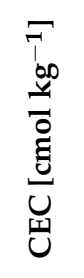 & $\frac{\bar{o}}{\infty}$ & 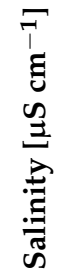 & $\begin{array}{l}F \\
100 \\
\frac{60}{y} \\
000 \\
\overrightarrow{0} \\
\overrightarrow{0} \\
\vec{Z}\end{array}$ & 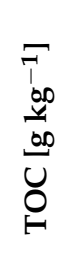 & 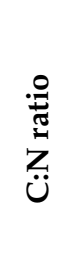 & 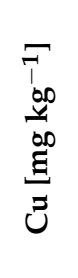 \\
\hline $\begin{array}{c}\text { Cambisols- } \\
\text { Brown } \\
\text { Soil }^{1}\end{array}$ & 6.44 & 7.07 & 2.46 & 6.57 & 9.03 & 72.75 & 0.89 & 0.58 & 4.79 & 8.26 & 18.21 \\
\hline
\end{tabular}
total nitrogen; TOC: total organic carbon; ${ }^{1}$ IUSS Working Group WRB [37].

The experiment was set up in polyethylene pots filled with $8 \mathrm{~kg}$ of soil sieved through a sieve with a mesh diameter of $1 \mathrm{~cm}$. During the vegetative growth, the moisture of the soil in the pots was kept at the level of $60 \%$ of full water capacity. Black mustard (Brassica nigra L. Koch) of the local population (PPH "PIAST" Jan Kołodziej, Dębno) grown in the pots was harvested after the formation of pods (BBCH 71-79).

\subsection{Analytical Methods}

\subsubsection{Soil Analysis}

Before setting up the experiment in the starting soil, the particle size distribution was determined using a Mastersizer 3000 (Malvern Instruments Limited, Worcestershire, UK). Then, after sieving through a sieve with a mesh diameter of $2 \mathrm{~mm}$, the soil $\mathrm{pH}, \mathrm{HAC}, \mathrm{TEB}$, CEC, BS, salinity, $\mathrm{N}_{\text {tot }}, \mathrm{TOC}, \mathrm{C}: \mathrm{N}$ ratio and total copper content $(\mathrm{Cu})$ were determined. Soil analyses were performed using the following methods. Soil $\mathrm{pH}(\mathrm{pH})$ was determined potentiometrically in water and in soil $1 \mathrm{M} \mathrm{KCl}^{-1}$ solution in the ratio of 1:2.5 $(w / v)$, using a pH SenTix61 electrode and pH 538 WTW potentiometer (WTW, Wrocław, Poland). EC was determined in a mixture of soil/deionized water in the ratio of $1: 2(w / v)$ with a portable multi-range conductivity meter HI-8733 (Hanna Instruments, Leighton Buzzard, United Kingdom). HAC and TEB were determined with the Kappen's method [38], and the results were used to calculate CEC (1) and BS (2) according to the following formulas:

$$
\begin{gathered}
\mathrm{CEC}=\mathrm{HAC}+\mathrm{TEB} \\
\mathrm{BS}=\frac{\mathrm{TEB}}{\mathrm{CEC}} \times 100
\end{gathered}
$$

The content of $\mathrm{N}_{\text {tot }}$ was determined by the Kjeldahl method [38], and the total organic carbon (TOC) content was determined on a Shimadzu TOC-L analyzer (Shimadzu Corporation, Kyoto, Japan) coupled with a module SSM-5000A for solid samples. Total Cu content 
in soil was determined in the samples mineralized according to the US-EPA3051 protocol in a MARS 5 microwave oven (CEM Corporation, Matthews, NC, USA) in a mixture of acids: $65 \% \mathrm{HNO}_{3}$ and $38 \% \mathrm{HCl}$ mixed in a $4: 1$ ratio. The $\mathrm{Cu}$ content in soil was determined using an atomic absorption spectrophotometer SpectrAA-240FS (Varian Inc., Mulgrave, Australia), with reference standards by MERCK (Darmstadt, Germany).

\subsubsection{Plant Analysis}

Before the plants were harvested, the SPAD leaf greenness index was determined with a greenness measuring apparatus (SPAD-502 Chlorophyll Meter, Konica-Minolta, Tokyo, Japan). After harvesting, the yield and the content of $\mathrm{Cu}, \mathrm{N}_{\text {tot }}, \mathrm{P}, \mathrm{K}, \mathrm{Ca}, \mathrm{Mg}$ and $\mathrm{Na}$ were determined. After determining the yield of fresh weight from the pot, the plant samples were fragmented into pieces about $2 \mathrm{~cm}$ long and dried at $50{ }^{\circ} \mathrm{C}$ in a Binder FED 720 continuous airflow dryer (Binder GMBH, Tuttlingen, Germany) to determine the dry matter content. The samples were ground, and the $\mathrm{Cu}$ content was determined after digestion in $65 \% \mathrm{HNO}_{3}$ acid according to the US-EPA3052 protocol, in a MARS 5 microwave oven. The remaining components were determined after the mineralization of samples in concentrated sulfuric acid, with the addition of hydrogen peroxide as a catalyst. The samples thus prepared were submitted to the following determinations. The content of nitrogen was determined with the Kjeldahl distillation method in a Distillation Unit BUCHI K-355 (BÜCHI Labortechnik AG, Flawil, Switzerland), The vanadium molybdate colorimetric method was used to determine the phosphorus content $(\mathrm{P})$ [38]. Absorbance for $\mathrm{P}$ determination was measured at the wavelength of $470 \mathrm{~nm}$ in a $1 \mathrm{~cm}$ path length quartz cuvette using a flow spectrophotometer Specol 220 (Carl Zeiss Jena, Oberkochen, Germany). The content of potassium (K), calcium (Ca) and sodium (Na) was measured by atomic emission spectrometry (AES), and the content of magnesium (Mg) and copper $(\mathrm{Cu})$ was determined with the flame atomic absorption spectrophotometric method (FAAS) in a VARIAN SpectrAA-FS240 apparatus (Varian Inc., MulgraveAustralia) [38]. Ratios between the nutrients (macroelements) contained in black mustard plants were expressed as equivalent ratios $(\mathrm{K}, \mathrm{Na}, \mathrm{Ca}$ and $\mathrm{Mg}$ ) and as molar ratios ( $\mathrm{Ca}$ and $\mathrm{P}$ ). The equivalent ratios were calculated from the content of the nutrients expressed in $\mathrm{g} \mathrm{kg}^{-1} \mathrm{dm}$, and their gram equivalent weight $(+)\left(\mathrm{K}=39.098, \mathrm{Na}=22.989, \mathrm{Ca}=20.039\right.$ and $\left.\mathrm{Mg}=12.153 \mathrm{~g} \mathrm{val}(+)^{-1}\right)$. Due to the varying valence of phosphorus in chemical compounds, the Ca:P ratios were expressed as molar ones. This is how the Ca:P ratio is presented in the available research papers [39]. This ratio was calculated from the concentrations of $\mathrm{Ca}$ and $\mathrm{P}$ in plants, expressed in $\mathrm{g} \mathrm{kg}^{-1} \mathrm{DM}$, and their molar mass $\left(\mathrm{Ca}=40.078, \mathrm{P}=30.972 \mathrm{~g} \mathrm{~mol}^{-1}\right)$.

\subsubsection{Experimental Data Analysis}

The results were processed statistically with ANOVA at the level of significance of $\alpha \leq 0.05$, using a Statistica ${ }^{\circledR}$ v. 13.3 PL software package from TIBCO Software Inc (Palo Alto, CA, USA) [40]. The correlation between the analyzed factors was established using a simple linear correlation model, with the Microsoft Excel ${ }^{\circledR}$ for Microsoft 365 MSO [41].

\section{Results and Discussion}

\subsection{Leaf Greenness-SPAD Index}

Soil contamination with copper significantly modified the leaf greenness (SPAD index) of the tested plants (Figure 1). In the series without neutralizing materials, a significant increase in greenness in relation to the control object was shown in objects contaminated with 200 and 400 and $600 \mathrm{mg} \mathrm{Cu} \mathrm{kg}^{-1}$ of soil. The interaction between the examined factors indicated that the SPAD index reacted differently to the NMs applied in the mentioned objects. First, it was found that a 3\% addition of zeolite to uncontaminated soil significantly increased the SPAD index, which was not demonstrated for clay and lime. Comparing the SPAD index of objects with higher copper content in relation to the control object (without NMs), it was found that zeolite completely eliminated the effect caused by the increase in the soil copper concentration, i.e., the chlorophyll content decreased linearly due to 
the increasing $\mathrm{Cu}$ content in the soil. Similar results were obtained in the series with the addition of clay, but only for objects with 200 and $400 \mathrm{mg} \mathrm{Cu} \mathrm{kg}^{-1}$ of soil. The addition of lime did not bring any significant changes in relation to the control series.
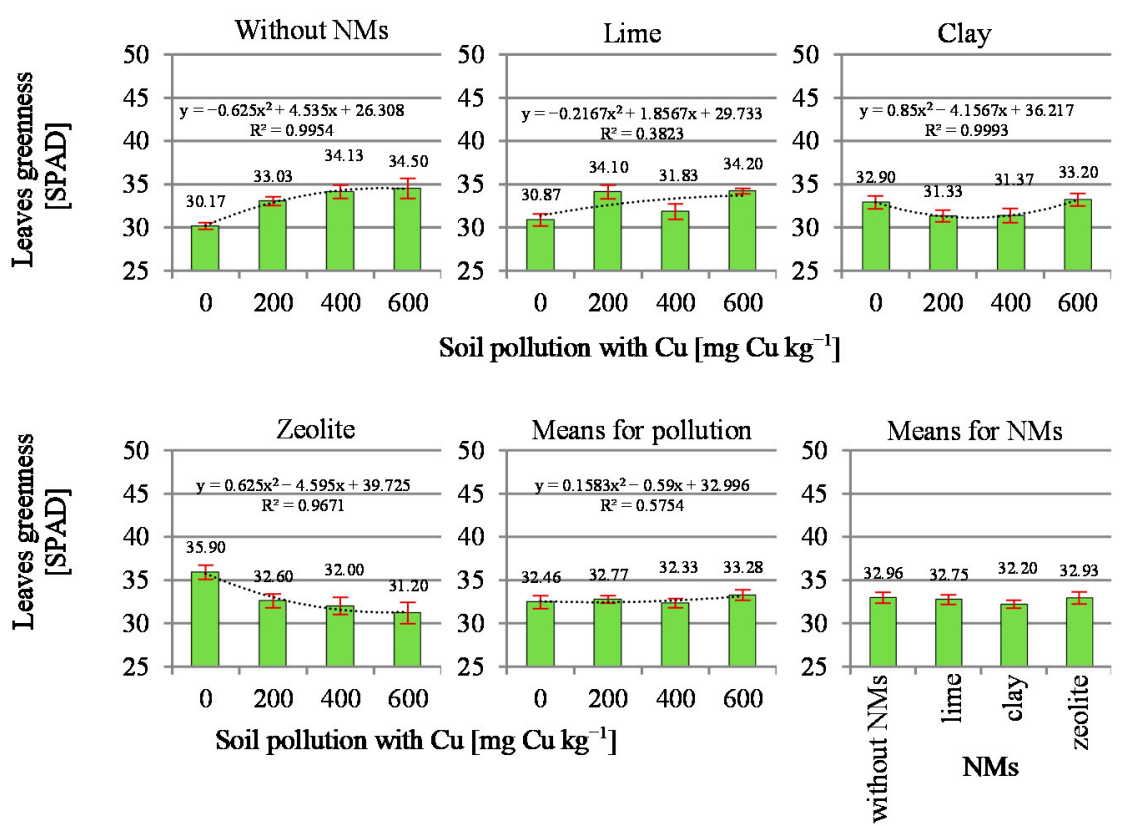

$\operatorname{LSD}_{\alpha \leq 0.05}$ for soil pollution $=$ n.s.; for NMs $=$ n.s.; for interaction $=2.83 ; n=3$

Figure 1. The greenness of the leaves of black mustard (Brassica nigra L. Koch).

Leaf greenness index (SPAD) is a reliable indicator for the nutritional status of plants. In precision agriculture, it is used in particular to determine the plant demand for nitrogen fertilization, which is directly correlated with the yield [42-44]. The results indicate that SPAD may be useful in the observation of changes in plant pigments (chlorophylls) caused by environmental stress factors, e.g., the influence of heavy metals, salinity, etc. Research on the content of chlorophyll in scentless mayweed plants in the vicinity of a copper smelter conducted by Dopierała [15] showed that, in this case, the chlorophyll content was relatively stable up to the contamination level of $200 \mathrm{mg} \mathrm{Cu} \mathrm{kg}^{-1}$ of soil, and increasing pollution caused a slight decrease in greenness. The present research showed that $200 \mathrm{mg} \mathrm{Cu} \mathrm{kg}^{-1}$ as a stressor was already high enough to induce an increase in the content of chlorophyll in leaves. A similar effect of increasing the content of chlorophyll under the influence of copper was shown by Feil et al. [45]. The authors, using low concentrations of copper $\left(5 \mu \mathrm{M} \mathrm{Cu} \mathrm{dm}^{-3}\right)$ in the medium in which cucumbers were grown, showed a decrease in the SPAD index by 0.5 units compared to the control object $\left(0.2 \mu \mathrm{M} \mathrm{Cu} \mathrm{dm}{ }^{-3}\right)$, while in higher concentrations of $\mathrm{Cu}\left(25\right.$ and $\left.50 \mu \mathrm{M} \mathrm{Cu} \mathrm{dm}{ }^{-3}\right)$, the SPAD index increased by 1.7 and 9.3 units. Disruptions in the biosynthesis of chlorophyll are one of the most negative consequences resulting from the toxicity of copper for plants [12]. High soil contamination with copper results in reduced plant growth and leaf chlorosis [33], and as a result of the formation of reactive oxygen species (ROS), it contributes to oxidative stress and thus disrupts metabolic pathways and causes damage to macromolecules [46-48]. The presented data indicate that increasing the content of minerals such as zeolite and clay in copper-contaminated sites may significantly modify the content of chlorophyll in leaves of cultivated plants.

\subsection{Plant Yield and Dry Matter Content}

The high toxicity of $\mathrm{Cu}$ manifested by the above-mentioned disturbances in the synthesis of chlorophyll has a direct impact on the biomass yield of plants. In the present research, the black mustard yield (Figure 2) depended on both soil contamination and the applied NMs. As the level of contamination increased, the yield decreased significantly. 
In the series without NMs, at the level of $200 \mathrm{mg} \mathrm{Cu} \mathrm{kg}^{-1}$, this decrease was on average $33.8 \%$ in relation to the fresh weight of plants in the control sample, while contamination at the higher levels of 400 and $600 \mathrm{mg} \mathrm{Cu} \mathrm{kg}^{-1}$ resulted in a reduction of the yield by $75.5 \%$ and $92.4 \%$, respectively. The NMs significantly influenced the differentiation of the results in relation to the control series without NMs. The use of lime significantly reduced the toxicity of copper, even effecting an increase in the plant yield in relation to the yield obtained in the control object. It was most visible for the level of $200 \mathrm{mg} \mathrm{Cu} \mathrm{kg}{ }^{-1}$, where, in relation to the series without NMs, the increase in the yield amounted to $7.6 \%$ in relation to the control. With regard to the higher concentrations of copper in the soil, no mitigating effect of lime was demonstrated. The remaining NMs did not reduce the harmful effects of copper. In the case of zeolite, the mitigating effect on copper was observed in objects contaminated with $\mathrm{Cu}$ at the level of $400 \mathrm{mg} \mathrm{kg}^{-1}$ and $600 \mathrm{mg} \mathrm{kg}^{-1}$. However, this effect was not statistically proven, but the yields obtained in this series, compared to those harvested in the series without NMs, were higher by 13.7 and $14.4 \mathrm{~g} \mathrm{pot}^{-1}$, respectively. The results indicate that the $\mathrm{Cu}$ content in the soil at the level of $200 \mathrm{mg} \mathrm{kg}^{-1}$ results in a decrease in plant biomass yield. The toxic effect of $\mathrm{Cu}$ on plants, reflected in reduced yield, was demonstrated in the research by Xu et al. [49]. In the cultivation of rice, at the levels of copper contamination used by the authors, yield dropped by $10.1 \%$ for $100 \mathrm{mg} \mathrm{Cu} \mathrm{kg}^{-1}$, $15.4 \%$ for $200 \mathrm{mg} \mathrm{Cu} \mathrm{kg}^{-1}, 37.0 \%$ for $400 \mathrm{mg} \mathrm{Cu} \mathrm{kg}^{-1}, 8.9 \%$ for $600 \mathrm{mg} \mathrm{Cu} \mathrm{kg}^{-1}, 89.3 \%$ for $800 \mathrm{mg} \mathrm{Cu} \mathrm{kg}^{-1}$ and $96.2 \%$ for $1000 \mathrm{mg} \mathrm{Cu} \mathrm{kg}^{-1}$ compared to unpolluted objects. Among the NMs used in the present research, lime significantly reduced the toxic effect of copper, even causing an increase in the yield in the object with $200 \mathrm{mg} \mathrm{Cu} \mathrm{kg}{ }^{-1}$. The addition of NMs improved the use of the soil nutrients and fertilizers by plants. According to Plyatsuk [2] and Derakhshan Nejad et al. [50], lime has a significant effect on the soil microflora. In addition, the ability of roots to absorb a number of heavy metals, in particular lead, decreases as a result of an increase of the Ca content in the soil and more intensive encrustation of the root cell walls with these components. Liming also contributes to the formation of complexes of soil organic substances with metals, which reduces the mobility of $\mathrm{Cu}$ and $\mathrm{Hg}, \mathrm{Cd}, \mathrm{Zn}, \mathrm{Ni}$ and $\mathrm{Cr}$.
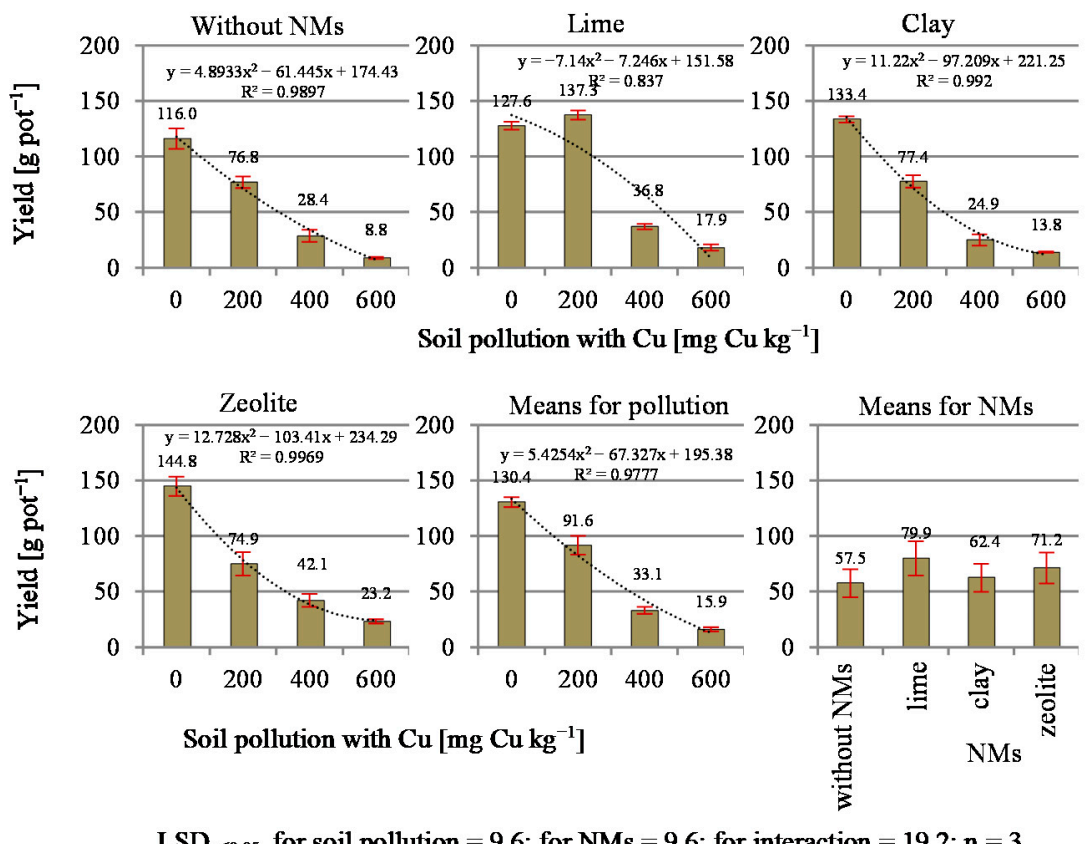

Figure 2. The yield of aerial mass of black mustard (Brassica nigra L. Koch).

The dry matter (DM) content in the test plant (Figure 3) was highly dependent on the increasing level of soil contamination with copper and the applied NMs. Along with the increase in soil contamination, a decrease in the dry matter content was observed. The great- 
est decrease in DM content (36.0\% on average) occurred between 0 and $200 \mathrm{mg} \mathrm{Cu} \mathrm{kg}{ }^{-1}$. The demonstrated interaction suggests that the NMs modified the DM content in different ways at certain levels of soil contamination with copper. Similarly to its effect on yield, the addition of lime applied in the object contaminated with $200 \mathrm{mg} \mathrm{Cu} \mathrm{kg}^{-1}$ significantly increased the DM content of plants compared to the control object, i.e., without NMs, and those where clay or zeolite were used. A similar effect after the application of lime was found in a study on neutralization of the toxic effect of copper on maize [7].
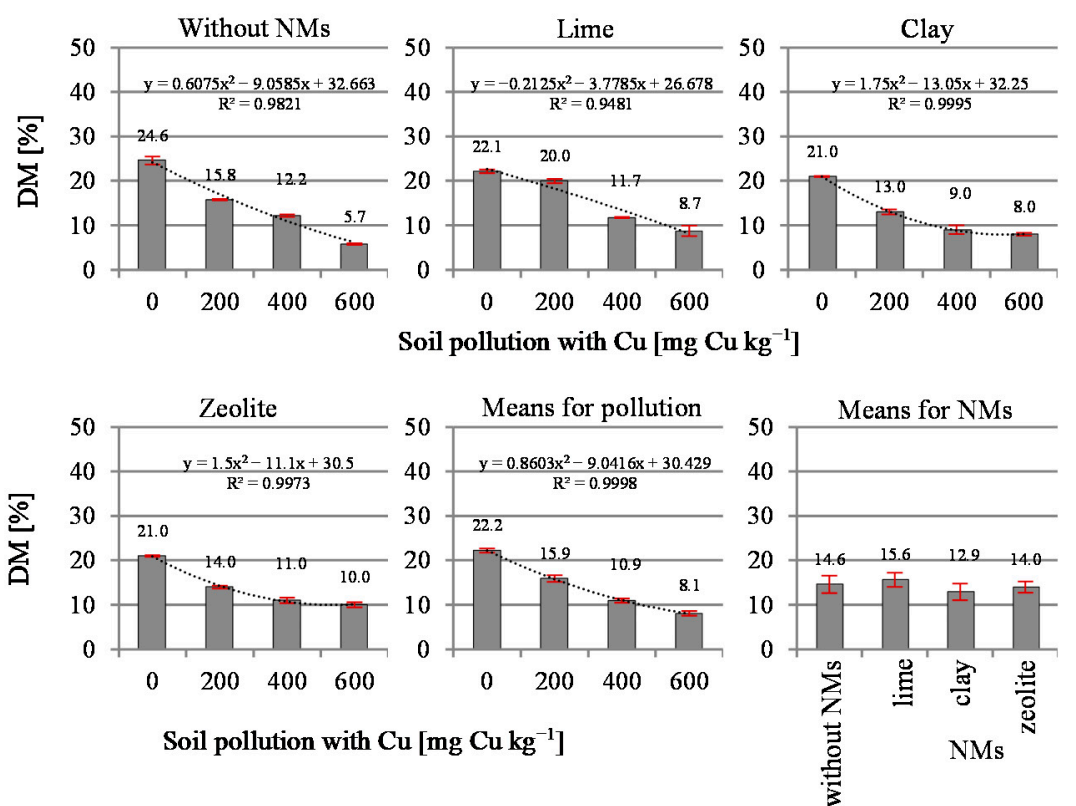

$\mathrm{LSD}_{\alpha \leq 0.05}$ for soil pollution $=0.98$; for $\mathrm{NMs}=0.98$; for interaction $=1.97 ; \mathrm{n}=3$

Figure 3. Content of dry mass in black mustard (Brassica nigra L. Koch).

In the case of this plant, the addition of lime used in objects contaminated with copper at the level of $200 \mathrm{mg} \mathrm{Cu} \mathrm{kg}^{-1}$ resulted in an increase in the dry matter content in relation to the control sample. These results correspond with the research by Szatanik-Kloc [51], who showed a stressful effect of copper on plants in trials with increasing copper contamination, resulting in a decrease in the dry matter content of plants compared to the control sample. In addition, varied responses of different plant species to copper contamination have been demonstrated. For example, wheat and clover were more susceptible to stress than rye and lupines.

A previous study conducted by Żołnowski et al. [7] showed that a dose of $200 \mathrm{mg} \mathrm{Cu} \mathrm{kg}^{-1}$ of soil had a stimulating effect, increasing the maize root yield in relation to the control object. The authors did not find such an action in relation to the aerial mass of maize. The present research has shown that in the case of black mustard sown in sites where copper contamination reaches up to $200 \mathrm{mg} \mathrm{Cu} \mathrm{kg}^{-1}$ soil, lime is a good neutralizer, limiting the element's toxic effect. For higher copper concentrations, zeolite is a better alternative.

\subsection{Chemical Composition of Plants}

The $\mathrm{Cu}$ content in plants was varied and determined by the $\mathrm{Cu}$ content in the soil (Table 2). In all series, it was shown that the $\mathrm{Cu}$ content was significantly affected by the level of $200 \mathrm{mg} \mathrm{Cu} \mathrm{kg}^{-1}$ of soil. The tendency for a further increase in the copper content in the tissues of black mustard was also demonstrated in relation to the level of $400 \mathrm{mg} \mathrm{Cu} \mathrm{kg}^{-1}$ of soil in the series without NMs and with the addition of lime and of clay. In the series with the addition of zeolite, a tendency to decrease the copper content was demonstrated under the influence of $400 \mathrm{mg} \mathrm{Cu} \mathrm{kg}^{-1}$ of soil. The dose of $600 \mathrm{mg} \mathrm{Cu} \mathrm{kg}^{-1}$ of soil in each of the tested objects caused a decrease in the copper content in relation to objects contaminated with $400 \mathrm{mg} \mathrm{Cu} \mathrm{kg}^{-1}$ of soil. The observed 
after the application of $6.6 \mathrm{Mg}$ of lime ha ${ }^{-1}$ to soil with $\mathrm{pH}=3.8$, the $\mathrm{Cu}$ concentration in plants was $21.0 \%$ lower compared to the objects without liming. At the same time, the authors emphasize the significant influence of zeolite, which, when applied at a dose of $3.3-10.0 \%$ of the soil mass on the 50th day of the research, was more effective than lime in reducing copper uptake. As a result, the authors showed that zeolite used with lime reduced the $\mathrm{Cu}$ concentration by $43.0 \%$. In the present study, the soil was characterized by much higher $\mathrm{pH}\left(\mathrm{pH}_{\mathrm{KCl}}=6.44\right)$, at which the effect demonstrated by Antoniadis and Damalidis [61] was not observed after the application of zeolite.

The content of total nitrogen $\left(\mathrm{N}_{\text {tot }}\right)$ (Table 3 ) in black mustard yield was significantly differentiated and depended on the level of copper contamination and the NMs used. The increasing pollution stimulated the accumulation of nitrogen compounds (up to $400 \mathrm{mg} \mathrm{Cu} \mathrm{kg}^{-1}$ ). The applied lime decreased the amount of nitrogen accumulation in the plant compared to the control series, while the NMs in the form of clay and zeolite increased the $\mathrm{N}_{\text {tot }}$ content in the test plant. The increase in the content of $\mathrm{N}_{\text {tot }}$ in plants basically occurred only up to the level of $400 \mathrm{mg} \mathrm{Cu} \mathrm{kg}^{-1}$. The pollution with $600 \mathrm{mg} \mathrm{Cu} \mathrm{kg}^{-1}$ decreased the $\mathrm{N}_{\text {tot }}$ content in plant tissue.

Table 3. Total nitrogen, phosphorus and potassium content in black mustard (Brassica nigra L. Koch).

\begin{tabular}{|c|c|c|c|c|c|c|c|c|c|c|}
\hline \multirow{2}{*}{$\begin{array}{l}\text { Soil Pollution } \\
\text { with } \mathrm{Cu} \\
\left(\mathrm{mg} \mathrm{kg}^{-1}\right)\end{array}$} & \multirow{2}{*}{\multicolumn{2}{|c|}{ Without NMs }} & \multicolumn{6}{|c|}{ Neutralizing Materials } & \multirow{2}{*}{\multicolumn{2}{|c|}{ Mean }} \\
\hline & & & \multicolumn{2}{|l|}{ Lime } & \multicolumn{2}{|l|}{ Clay } & \multicolumn{2}{|c|}{ Zeolite } & & \\
\hline \multicolumn{11}{|c|}{ Ntot $\left(\mathrm{g} \mathrm{kg}^{-1} \mathrm{DM}\right)$} \\
\hline 0 & $9.88 \pm 0.46$ & $\mathrm{a}$ & $13.30 \pm 0.07$ & $\mathrm{~b}$ & $21.70 \pm 0.07$ & $\mathrm{~d}$ & $21.84 \pm 0.13$ & d & $16.68 \pm 1.51$ & A \\
\hline 200 & $28.56 \pm 0.00$ & e & $19.46 \pm 0.07$ & c & $36.40 \pm 0.13$ & $\mathrm{~g}$ & $39.48 \pm 0.26$ & ij & $30.98 \pm 2.24$ & B \\
\hline 400 & $36.26 \pm 0.07$ & $\mathrm{~g}$ & $32.62 \pm 0.07$ & $\mathrm{f}$ & $42.28 \pm 0.66$ & 1 & $41.30 \pm 0.07$ & $\mathrm{kl}$ & $38.12 \pm 1.14$ & $\mathrm{D}$ \\
\hline 600 & $37.38 \pm 0.07$ & gh & $32.76 \pm 0.00$ & f & $40.32 \pm 0.13$ & $\mathrm{jk}$ & $38.78 \pm 0.20$ & hi & $37.31 \pm 0.82$ & $\mathrm{C}$ \\
\hline Mean: & $28.02 \pm 3.18$ & B & $24.54 \pm 2.44$ & A & $35.18 \pm 2.33$ & $\mathrm{C}$ & $35.35 \pm 2.27$ & $\mathrm{C}$ & 30.77 & \\
\hline$r$ & 0.92 & $* *$ & 0.95 & $* *$ & 0.85 & $* *$ & 0.75 & * & - & \\
\hline \multicolumn{11}{|c|}{ LSD $\alpha \leq 0.05$ for increasing Cu soil pollution $=0.73 ;$ for $\mathrm{NMs}=0.73 ;$ for interaction $=1.46$} \\
\hline \multicolumn{11}{|c|}{$\mathrm{P}\left(\mathrm{g} \mathrm{kg}^{-1} \mathrm{DM}\right)$} \\
\hline 0 & $3.89 \pm 0.04$ & & $5.93 \pm 1.07$ & & $4.10 \pm 0.04$ & & $3.95 \pm 0.01$ & & $4.47 \pm 0.36$ & B \\
\hline 200 & $3.01 \pm 0.08$ & & $4.02 \pm 0.02$ & & $3.22 \pm 0.00$ & & $3.09 \pm 0.02$ & & $3.34 \pm 0.12$ & B \\
\hline 400 & $2.38 \pm 0.01$ & & $2.62 \pm 0.10$ & & $3.05 \pm 0.00$ & & $2.80 \pm 0.00$ & & $2.71 \pm 0.07$ & $\mathrm{AB}$ \\
\hline 600 & $2.15 \pm 0.03$ & & $2.01 \pm 0.01$ & & $2.06 \pm 0.00$ & & $2.32 \pm 0.02$ & & $2.14 \pm 0.04$ & A \\
\hline Mean: & $2.86 \pm 0.20$ & & $3.64 \pm 0.51$ & & $3.11 \pm 0.21$ & & $3.04 \pm 0.17$ & & $3.16 \pm 0.04$ & \\
\hline$r$ & -0.96 & $* *$ & -0.78 & $*$ & -0.97 & $* *$ & -0.97 & $* *$ & & \\
\hline \multicolumn{11}{|c|}{$\mathrm{LSD} \alpha \leq 0.05$ for increasing Cu soil pollution $=0.86 ;$ for $\mathrm{NMs}=\mathrm{ns} ;$ for interaction $=\mathrm{ns}$} \\
\hline \multicolumn{11}{|c|}{$\mathrm{K}\left(\mathrm{g} \mathrm{kg}^{-1} \mathrm{DM}\right)$} \\
\hline 0 & $17.14 \pm 0.12$ & $\mathrm{ab}$ & $14.41 \pm 0.23$ & $\mathrm{a}$ & $15.88 \pm 0.24$ & $\mathrm{ab}$ & $17.70 \pm 0.86$ & $\mathrm{ab}$ & $16.28 \pm 0.43$ & A \\
\hline 200 & $22.91 \pm 0.28$ & $\mathrm{bc}$ & $20.98 \pm 1.19$ & $\mathrm{abc}$ & $24.09 \pm 0.00$ & $\mathrm{bc}$ & $23.51 \pm 0.56$ & $\mathrm{bc}$ & $22.87 \pm 0.48$ & B \\
\hline 400 & $42.25 \pm 1.27$ & $f$ & $34.56 \pm 3.79$ & de & $28.11 \pm 0.15$ & $\mathrm{~cd}$ & $21.20 \pm 0.53$ & $a b c$ & $31.53 \pm 2.46$ & C \\
\hline 600 & $36.29 \pm 1.18$ & ef & $28.75 \pm 0.15$ & cde & $28.76 \pm 0.46$ & cde & $22.33 \pm 0.00$ & $a b c$ & $29.03 \pm 1.46$ & $\mathrm{C}$ \\
\hline Mean: & $29.65 \pm 2.94$ & B & $24.68 \pm 2.42$ & A & $24.21 \pm 1.49$ & A & $21.19 \pm 0.69$ & A & 24.93 & \\
\hline$r$ & 0.84 & $* *$ & 0.73 & $*$ & 0.92 & $* *$ & 0.52 & ns & - & \\
\hline \multicolumn{11}{|c|}{ LSD $\alpha \leq 0.05$ for increasing Cu soil pollution $=3.60 ;$ for $\mathrm{NMs}=3.60 ;$ for interaction $=7.21$} \\
\hline
\end{tabular}

Means followed by different letters are significantly different by the LSD $\alpha \leq 0.05$ test; ${ }^{*}$ - correlation coefficient $r$ significant for $\alpha \leq 0.05$;

** - correlation coefficient $r$ significant for $\alpha \leq 0.01$; ${ }^{\text {ns }}$-non significant; $\mathrm{n}=3$.

The content of minerals in the yield of plants depends on the efficiency of nutrient uptake. The uptake depends on the mechanism of ion transportation from the soil solution to the root and further through the cells of the tissues conducting to the stem, leaves, flowers and fruits. It takes place through the root cell membranes, with the participation of the so-called transport proteins [62]. This transport is effective up to a specific (borderline) content of the component in the soil, above which problems resulting from soil salinity most often occur. In contaminated soils, the component limiting the uptake of nutrients, and thus the content of elements in plants, is considered to be a contaminant. With regard to the content of copper in soil and nitrogen in plant biomass, there are a number of studies confirming the synergism between these elements. Such results were obtained by 
Kuziemska et al. [63]. In that research, the nitrogen content of cocksfoot grass biomass increased in the first year of cultivation as a result of the increasing copper content in the soil (100-300 mg Cu kg${ }^{-1}$ ). In addition, Snowball et al. [64], with reference to subterranean clover, and Alhasany et al. [65], in relation to broad bean, reported a synergistic effect of these two elements. On the other hand, the research of Meller and Jarnuszewski [66] shows no relationship between copper fertilization and the $\mathrm{N}$ content in the biomass of maize, spring barley, spring wheat, white mustard, spring oilseed rape and common oat. The data published by Rietra et al. [62] also indicate the lack of antagonistic and synergistic interactions between copper and nitrogen.

In this study, a synergistic effect of $\mathrm{Cu}$ on the uptake and $\mathrm{N}_{\text {tot }}$ content in black mustard biomass up to the dose of $400 \mathrm{mg} \mathrm{Cu} \mathrm{kg}{ }^{-1}$ of soil was observed. After exceeding this level of soil contamination with $\mathrm{Cu}$, an antagonistic effect of this metal in relation to $\mathrm{N}$ was observed.

Along with the increase in the soil contamination with copper, a decrease in the $\mathrm{P}$ content in plants was shown (Table 3). The lowest $\mathrm{P}$ content was found for $600 \mathrm{mg} \mathrm{Cu} \mathrm{kg}{ }^{-1}$ soil. The applied NMs did not significantly change the P content in black mustard plants, although a noticeable decrease in the P content was observed in each series under the influence of increasing contamination. The highest average content of $\mathrm{P}$ was found in the series with the addition of lime $(24.1 \%$ higher than in the series without neutralizing agents). The antagonistic effect of $\mathrm{Cu}$ on the P content was confirmed by Feil et al. [45]. Cucumber plants treated with the highest concentration of $\mathrm{Cu}$ showed, significantly, the lowest concentration of $\mathrm{P}$ in both shoots and roots, decreased by approximately 32 and $36.0 \%$, respectively, compared to the control. In addition, Szatanik-Kloc [51] found in her research the antagonism of $\mathrm{Cu}$ against $\mathrm{P}$ in tissues of clover, wheat and rye. According to the author, reduction of the $\mathrm{P}$ content in plant tissues is most often associated with a change in the permeability of cell membranes, which are responsible for the transport of ions such as $\mathrm{PO}_{4}{ }^{3-}$ or $\mathrm{K}^{+}$[17].

Soil contamination with copper significantly influenced the potassium content in plants (Table 3). The highest content of this element in plants in most of the experimental series was found at the $\mathrm{Cu}$ pollution equal to $400 \mathrm{mg} \mathrm{kg}^{-1}$ of soil. In the series without $\mathrm{NMs}$, it was $42.25 \mathrm{~g} \mathrm{~K} \mathrm{~kg}^{-1} \mathrm{DM}$, and this value was more than twice as high as in the control sample. The highest soil contamination with copper, $600 \mathrm{mg} \mathrm{Cu} \mathrm{kg}^{-1}$, resulted in a decrease in the $\mathrm{K}$ content by $14.1 \%$, which was probably related to toxic effect. All the NMs caused a decrease in the mean potassium content compared to the control object without NMs. The potassium content in plants was lowered the most by clay, then by zeolite and lime.

Changes in the content of $\mathrm{Ca}, \mathrm{Mg}$ and $\mathrm{Na}$, as in the case of $\mathrm{K}$, differed depending on the increasing level of pollution and the NMs used (Table 4). The content of these elements in the control series increased to the pollution level of $400 \mathrm{mg} \mathrm{Cu} \mathrm{kg}^{-1}$. At the level of $600 \mathrm{mg} \mathrm{kg}^{-1}$, a decrease in the content of these elements was observed. The applied NMs in the form of lime and zeolite contributed to an increase in the Ca content, which was not demonstrated for clay. Concerning $\mathrm{Mg}$, its decrease was noted after the use of clay and lime. The average Na content was stimulated by the use of zeolite, whereas lime and clay significantly reduced the content of this element in plants. Summing up, soil contamination with $\mathrm{Cu}$ up to the level of $400 \mathrm{mg} \mathrm{kg}^{-1}$ contributed to an increase in the content of potassium, calcium, magnesium and sodium. At higher pollution, i.e., $600 \mathrm{mg} \mathrm{Cu} \mathrm{kg}^{-1}$, a decrease in the content of these macronutrients was observed. A decrease in the content of calcium and magnesium in plants correlating with an increase in copper contamination was also confirmed in the studies by Szatanik-Kloc [51] and Alaouis-Sosse et al. [67]. 
Table 4. Calcium, magnesium and sodium content in black mustard (Brassica nigra L. Koch).

\begin{tabular}{|c|c|c|c|c|c|c|c|c|c|c|}
\hline \multirow{2}{*}{$\begin{array}{c}\text { Soil Pollution } \\
\text { with } \mathrm{Cu}(\mathrm{mg} \\
\left.\mathrm{kg}^{-1}\right)\end{array}$} & \multirow{2}{*}{\multicolumn{2}{|c|}{ Without NMs }} & \multicolumn{6}{|c|}{ Neutralizing Materials } & \multirow{2}{*}{\multicolumn{2}{|c|}{ Mean }} \\
\hline & & & \multicolumn{2}{|l|}{ Lime } & \multicolumn{2}{|l|}{ Clay } & \multicolumn{2}{|c|}{ Zeolite } & & \\
\hline \multicolumn{11}{|c|}{$\mathrm{Ca}\left(\mathrm{g} \mathrm{kg}^{-1} \mathrm{DM}\right)$} \\
\hline 0 & $14.76 \pm 0.18$ & $\mathrm{bc}$ & $15.34 \pm 0.06$ & c & $12.98 \pm 0.04$ & a & $13.79 \pm 0.26$ & $\mathrm{ab}$ & $14.22 \pm 0.27$ & A \\
\hline 200 & $23.82 \pm 0.01$ & $\mathrm{~g}$ & $16.36 \pm 0.12$ & $\mathrm{~d}$ & $25.43 \pm 0.21$ & $\mathrm{~h}$ & $27.51 \pm 0.17$ & $\mathrm{i}$ & $23.28 \pm 1.22$ & C \\
\hline 400 & $25.51 \pm 0.16$ & $\mathrm{~h}$ & $31.39 \pm 0.04$ & $\mathrm{k}$ & $24.14 \pm 0.17$ & $\mathrm{~g}$ & $24.05 \pm 0.09$ & $\mathrm{~g}$ & $26.27 \pm 0.87$ & $\mathrm{D}$ \\
\hline 600 & $19.36 \pm 0.23$ & $\mathrm{e}$ & $29.19 \pm 0.07$ & j & $18.97 \pm 0.14$ & $\mathrm{e}$ & $20.68 \pm 0.22$ & $\mathrm{f}$ & $22.05 \pm 1.21$ & B \\
\hline Mean: & $20.86 \pm 1.21$ & A & $23.07 \pm 2.10$ & $\mathrm{C}$ & $20.38 \pm 1.42$ & A & $21.51 \pm 1.47$ & B & 21.46 & \\
\hline$r$ & 0.41 & ns & 0.87 & $* *$ & 0.38 & ns & 0.38 & ns & - & \\
\hline \multicolumn{11}{|c|}{$\mathrm{LSD}_{\alpha \leq 0.05}$ for increasing Cu soil pollution $=0.49 ;$ for amendments $=0.49 ;$ for interaction $=0.99$} \\
\hline \multicolumn{11}{|c|}{$\mathrm{Mg}\left(\mathrm{g} \mathrm{kg}^{-1} \mathrm{DM}\right)$} \\
\hline 0 & $1.70 \pm 0.05$ & $\mathrm{a}$ & $1.55 \pm 0.03$ & $\mathrm{a}$ & $1.80 \pm 0.01$ & $\mathrm{a}$ & $1.82 \pm 0.02$ & $\mathrm{a}$ & $1.72 \pm 0.03$ & A \\
\hline 200 & $5.74 \pm 0.05$ & $\mathrm{bc}$ & $2.12 \pm 0.06$ & $\mathrm{a}$ & $5.50 \pm 0.03$ & $\mathrm{~b}$ & $6.33 \pm 0.08$ & $\mathrm{~cd}$ & $4.92 \pm 0.48$ & B \\
\hline 400 & $8.39 \pm 0.02$ & $\mathrm{f}$ & $5.95 \pm 0.32$ & $\mathrm{bc}$ & $5.46 \pm 0.02$ & $\mathrm{~b}$ & $5.96 \pm 0.03$ & $\mathrm{bc}$ & $6.44 \pm 0.34$ & C \\
\hline 600 & $6.75 \pm 0.22$ & $\mathrm{~d}$ & $5.34 \pm 0.02$ & $\mathrm{~b}$ & $6.83 \pm 0.00$ & $\mathrm{~d}$ & $7.52 \pm 0.07$ & e & $6.61 \pm 0.24$ & C \\
\hline Mean: & $5.64 \pm 0.72$ & C & $3.74 \pm 0.56$ & A & $4.90 \pm 0.54$ & B & $5.41 \pm 0.62$ & C & 4.92 & \\
\hline$r$ & 0.80 & * & 0.87 & ** & 0.90 & ** & 0.87 & ** & - & \\
\hline \multicolumn{11}{|c|}{$\mathrm{LSD}_{\alpha \leq 0.05}$ for increasing $\mathrm{Cu}$ soil pollution $=0.33$; for amendments $=0.33$; for interaction $=0.67$} \\
\hline \multicolumn{11}{|c|}{$\mathrm{Na}\left(\mathrm{g} \mathrm{kg}^{-1} \mathrm{DM}\right)$} \\
\hline 0 & $1.00 \pm 0.02$ & c & $0.66 \pm 0.01$ & $\mathrm{~b}$ & $0.47 \pm 0.00$ & a & $0.55 \pm 0.01$ & $\mathrm{ab}$ & $0.67 \pm 0.06$ & A \\
\hline 200 & $2.51 \pm 0.03$ & $\mathrm{~d}$ & $0.39 \pm 0.00$ & $\mathrm{a}$ & $2.81 \pm 0.01$ & e & $4.23 \pm 0.06$ & j & $2.49 \pm 0.40$ & B \\
\hline 400 & $3.90 \pm 0.05$ & $\mathrm{~h}$ & $3.45 \pm 0.03$ & $\mathrm{~g}$ & $3.12 \pm 0.00$ & $\mathrm{f}$ & $3.95 \pm 0.03$ & $\mathrm{i}$ & $3.61 \pm 0.10$ & C \\
\hline 600 & $3.27 \pm 0.04$ & $\mathrm{i}$ & $2.74 \pm 0.02$ & $\mathrm{e}$ & $3.75 \pm 0.20$ & $\mathrm{~h}$ & $5.66 \pm 0.03$ & $\mathrm{k}$ & $3.86 \pm 0.32$ & $\mathrm{D}$ \\
\hline Mean: & $2.67 \pm 0.31$ & $\mathrm{C}$ & $1.81 \pm 0.38$ & A & $2.54 \pm 0.36$ & B & $3.60 \pm 0.54$ & $\mathrm{D}$ & 2.66 & \\
\hline$r$ & 0.84 & $* *$ & 0.79 & $*$ & 0.91 & $* *$ & 0.90 & $* *$ & - & \\
\hline \multicolumn{11}{|c|}{$\mathrm{LSD}_{\alpha \leq 0.05}$ for increasing Cu soil pollution $=0.09 ;$ for amendments $=0.49 ;$ for interaction $=0.18$} \\
\hline
\end{tabular}

Means followed by different letters are significantly different by the $\mathrm{LSD}_{\alpha \leq 0.05}$ test; ${ }^{*}$ - correlation coefficient $r$ significant for $\alpha \leq 0.05$; **_correlation coefficient $r$ significant for $\alpha \leq 0.01$; ${ }^{\text {ns _ }}$ non significant; $\mathrm{n}=3$.

\subsection{Ion Balance}

The quality of plants is expressed by both the total content of macronutrients and their mutual relations. Ionic ratios in plants are highly correlated with soil nutrient abundance. The inflow of various mineral and organic pollutants to the soil, through their synergism and antagonism, may significantly disturb the ionic balance of soils and thus directly affect the conditions of growth and development as well as the chemical composition of plants. Under production conditions, the analysis of this composition may indicate which components should be given particular attention when fertilizing plants. The ionic ratios in plants provided in scientific studies usually concern fodder plants $[68,69]$. Older works by other authors cited in these publications indicate that the optimal values of the ratios between individual ions in plants, expressed in milligram equivalents, are as follows: $\mathrm{K}:(\mathrm{Ca}+\mathrm{Mg})$ 1.6-2.2:1; K:Mg 6:1; K:Ca 2:1; K:Na 5-10:1; Ca:Mg 2-3:1; K:Ca 2:1 and the molar ratio of Ca:P 2:1.

The present study showed that increasing soil contamination with copper contributed to a significant extension of the $\mathrm{Ca}: \mathrm{P}$ molar ratio compared to the values adopted for forage plants (Figure 4). 
Without NMs

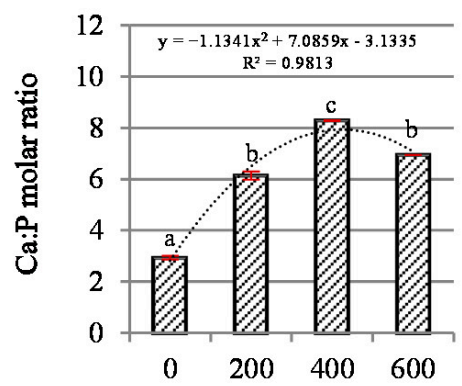

lime

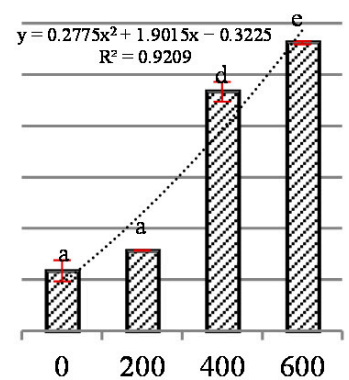

clay

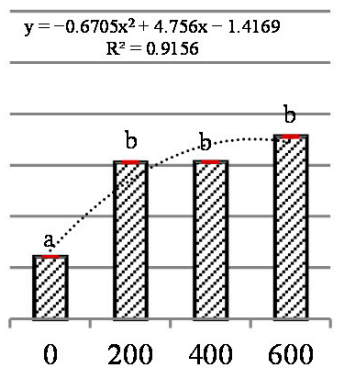

zeolite

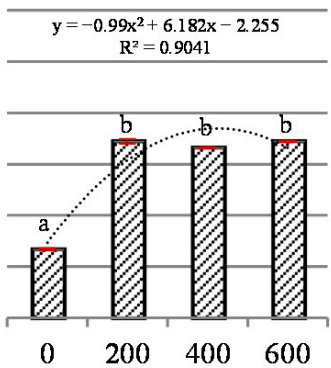

Soil pollution with $\mathrm{Cu}\left[\mathrm{mg} \mathrm{kg}^{-1}\right]$

Figure 4. The molar Ca:P ratio in dry mass of tissue of black mustard (Brassica nigra L. Koch).

This ratio should be about 2:1; meanwhile, the increasing $\mathrm{Cu}$ content in the soil increased this ratio to 6.14:1, 8.28:1 and 6.94:1 for 200, 400 and $600 \mathrm{mg} \mathrm{Cu} \mathrm{kg}^{-1}$ soil, respectively. The applied NMs did not significantly change the trend of the Ca:P ratio, with the exception of lime, which in response to 400 and $600 \mathrm{mg} \mathrm{Cu} \mathrm{kg}^{-1}$ soil additionally increased the already high values of these ratios to $10.33: 1$ and 11.24:1. The demonstrated broad Ca:P ratios can be associated with excessively low calcium content in plants. However, comparing the content of these elements in the black mustard samples to the average values in cultivated plants, which is in the range of $2-5 \mathrm{mg} \mathrm{P} \mathrm{kg}^{-1} \mathrm{DM}$ [38], and the tendency to change the $\mathrm{P}$ content under the influence of copper, it should be noted that the expansion of the Ca:P ratio is due to the decrease in the P content caused by the harmful effects of $\mathrm{Cu}$.

Soil contamination with $\mathrm{Cu}$ significantly influenced the Ca:Mg ratio in the test plant (Figure 5). In the control series, the narrowing of this ratio was observed from 5.29:1 for controls to $2.52: 1$ and $1.84: 1$ for 200 and $400 \mathrm{mg} \mathrm{Cu} \mathrm{kg}^{-1}$, respectively. Lime significantly widened the $\mathrm{Ca}: \mathrm{Mg}$ ratio compared to the series without $\mathrm{NMs}$, while the remaining mineral NMs did not significantly affect the formation of this indicator.
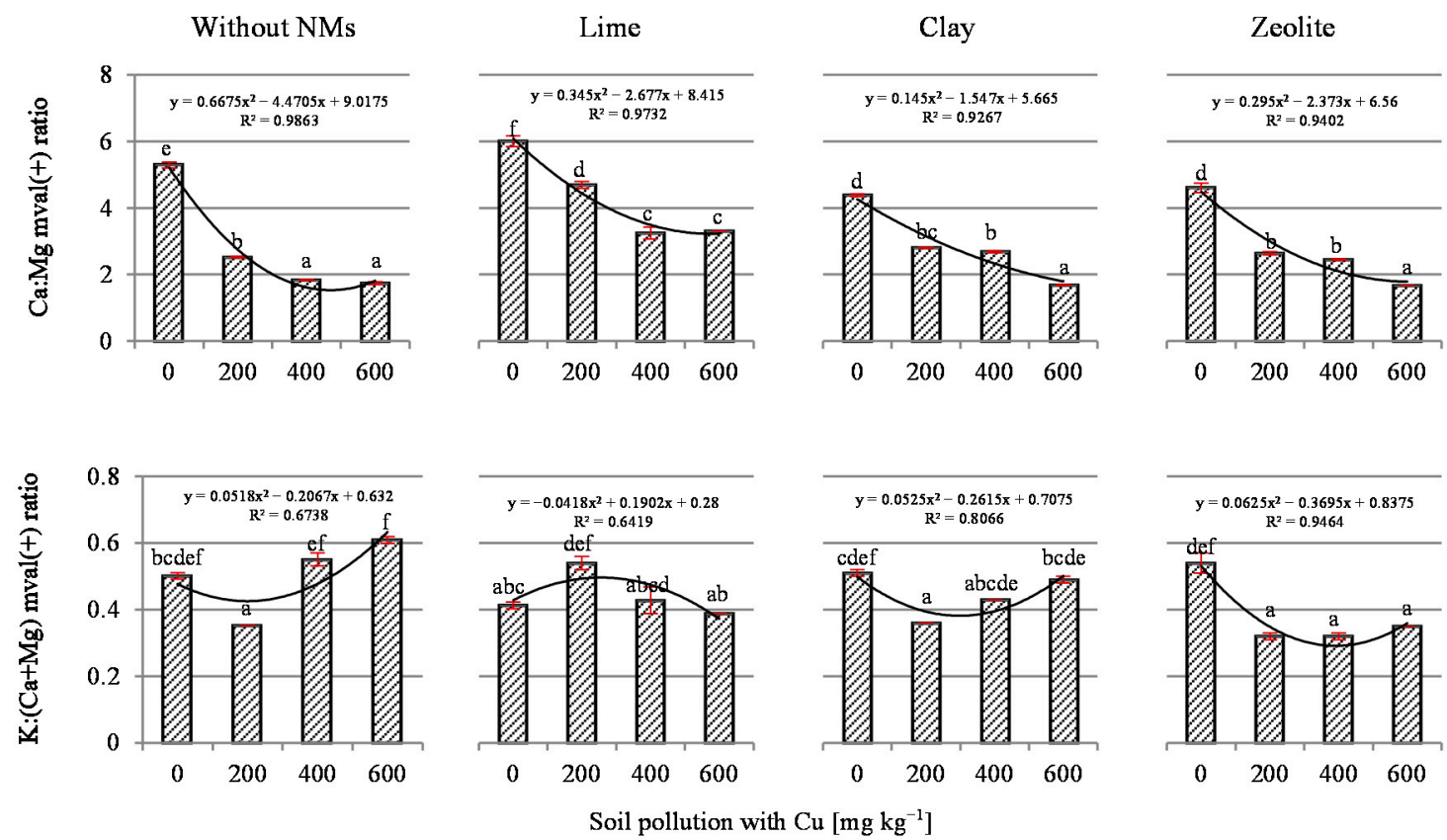

Different letters above the bars indicate significant differences between the treatments by the $\mathrm{LSD}_{\alpha \leq 0.05}$ test; $\mathrm{n}=3$

Figure 5. The Ca:Mg and $\mathrm{K}:(\mathrm{Ca}+\mathrm{Mg})$ ratio in dry mass of tissue of black mustard (Brassica nigra $\mathrm{L}$. Koch). 
The $\mathrm{K}:(\mathrm{Ca}+\mathrm{Mg})$ ratio in the analyzed mustard plants was narrowed under the influence of lime, but the other NMs did not modify this parameter significantly (Figure 5). It was found that the $\mathrm{K}:(\mathrm{Ca}+\mathrm{Mg})$ ratio was widened in the objects with $200-600 \mathrm{mg} \mathrm{Cu} \mathrm{kg}^{-1}$, but the value of 2.2 was never exceeded. The $\mathrm{K}:(\mathrm{Ca}+\mathrm{Mg})$ ratio higher than $2.2 \mathrm{in}$ animal feed may cause symptoms of tetany $[34,35,69]$.

The remaining equivalence ratios between individual ions, presented in Figure 6, developed in different ways and depended on the assessed elements, $\mathrm{Cu}$ contamination and the NMs used. With regard to the $\mathrm{K}: \mathrm{Mg}, \mathrm{K}: \mathrm{Ca}$ and $\mathrm{K}: \mathrm{Na}$ ratios, it was shown that $\mathrm{Cu}$ contamination generally led to the narrowing of these values. The results seem to confirm the significant narrowing of the $\mathrm{K}: \mathrm{Ca}$ and $\mathrm{K}: \mathrm{Mg}$ ratios under the influence of copper as observed by Jarnuszewski and Meller [70], who showed such changes in the straw of spring barley under the application of $\mathrm{Cu}$ as a micronutrient fertilizer. It should be stated, however, that the opposite tendency was observed in white mustard, spring oilseed rape and common oat, which indicates species-specific differences between agricultural plants with regard to the response to soil contamination with copper.
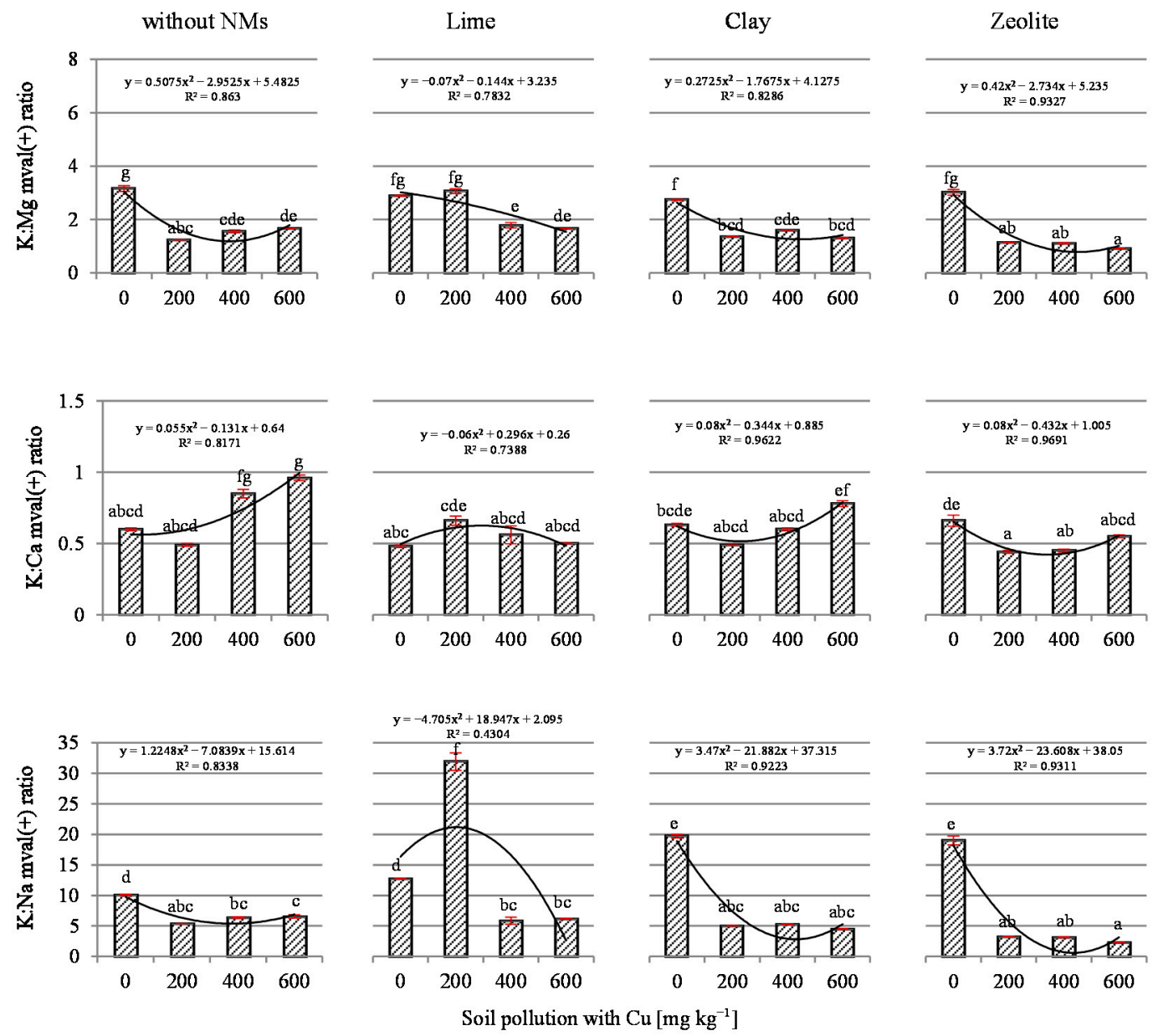

Different letters above the bars indicate significant differences between the treatments by the $\mathrm{LSD}_{\alpha \leq 0.05}$ test; $\mathbf{n}=3$

Figure 6. The $\mathrm{K}: \mathrm{Mg}, \mathrm{K}: \mathrm{Ca}$ and $\mathrm{K}: \mathrm{Na}$ ratios in dry mass of tissue of black mustard (Brassica nigra L. Koch).

\section{Conclusions}

In the present research, copper as a soil polluting factor influenced the yields and chemical composition of the plants obtained. The influence of $\mathrm{Cu}$ on the greenness of leaves became evident during the growing season. $\mathrm{Cu}$ stimulated plants to increase the production of chlorophyll to the level of $400 \mathrm{mg} \mathrm{Cu} \mathrm{kg}^{-1}$ soil. The addition of zeolite to soil with $400 \mathrm{mg} \mathrm{Cu} \mathrm{kg}^{-1}$ of soil and or clay to soil exposed to the entire range of simulated contamination counteracted these changes. 
Due to the increasing content of copper in the soil, the yield of plants and the dry matter content decreased sharply. The NMs mitigated this harmful influence, with clay, zeolite and lime in the increasing order of the mitigation effect. In the lime in objects contaminated with $200 \mathrm{mg} \mathrm{Cu} \mathrm{kg}^{-1}$ of soil, an increase in black mustard yield was observed in relation to the control.

Under the influence of soil contamination with $\mathrm{Cu}$, a linear increase in $\mathrm{Cu}$ concentration in plants was observed, with the maximum accumulation achieved at the contamination level of $400 \mathrm{mg} \mathrm{Cu} \mathrm{kg}^{-1}$ of soil. Above this level, a decrease in the $\mathrm{Cu}$ content in the aerial parts of plants was demonstrated. This effect could have been caused by the activation of copper sequestration mechanisms in the root tissue. The content of $\mathrm{K}, \mathrm{Mg}$, $\mathrm{Ca}$ and $\mathrm{Na}$ in plants increased to the level of $400 \mathrm{mg} \mathrm{Cu} \mathrm{kg}^{-1}$, while decreasing above this level, while the content of $\mathrm{P}$ decreased in proportion to the increasing pollution. Lime reduced the $\mathrm{Cu}$ accumulation in black mustard at all levels of contamination. Clay reduced the copper content in the objects with lower pollution (200 and $400 \mathrm{mg} \mathrm{Cu} \mathrm{kg}^{-1}$ ) and in the one not contaminated with $\mathrm{Cu}$ relative to the control series.

Copper, through interaction with other components, favored the narrowing of the $\mathrm{Ca}: \mathrm{Mg}, \mathrm{K}: \mathrm{Mg}$ and especially K:Na ratios and the expansion of the $\mathrm{Ca}: \mathrm{P}$ and $\mathrm{K}: \mathrm{Ca}$ ratios in plants. An unexpected exception was the object contaminated with $200 \mathrm{mg} \mathrm{Cu} \mathrm{kg}^{-1}$ fertilized with lime, where the value of K:Na increased to 31.90:1. Lime contributed to the extension of the Ca:P ratio, especially in objects contaminated with 400 and $600 \mathrm{mg} \mathrm{Cu} \mathrm{kg}^{-1}$. Lime also acted positively by expanding the $\mathrm{Ca} \mathrm{Mg}$ ratio compared to the series without NMs.

The most beneficial mineral raw material mitigating the effects of copper contamination was lime, followed by zeolite (especially at high copper concentrations).

Author Contributions: Conceptualization, A.C.Ż.; methodology, A.C.Ż.; software, A.C.Ż.; validation, A.C.Ż.; formal analysis, M.S. and E.R.; investigation, A.C.Ż., M.S. and E.R.; resources, A.C.Ż.; data curation, A.C.Ż.; writing-original draft preparation, A.C.Ż.; writing-review and editing, M.W. and E.R.; visualization, A.C.Ż.; supervision, A.C.Ż. and M.W.; project administration, M.W.; funding acquisition, M.W. All authors have read and agreed to the published version of the manuscript.

Funding: The results presented in this paper were obtained as part of a comprehensive study financed by the University of Warmia and Mazury in Olsztyn, Faculty of Environmental Management and Agriculture, Department of Environmental Chemistry (grant No. 20.610.003-110). The project was financially supported by the Minister of Education and Science in the range of the program entitled "Regional Initiative of Excellence" for the years 2019-2022, Project No. 010/RID/2018/19, amount of funding 12,000,000 PLN.

Institutional Review Board Statement: Not applicable.

Informed Consent Statement: Not applicable.

Data Availability Statement: Data are available by contacting the authors.

Conflicts of Interest: The authors declare no conflict of interest. The funders had no role in the design of the study; in the collection, analyses, or interpretation of data; in the writing of the manuscript, or in the decision to publish the results.

\section{References}

1. Hercer, M.; Wyszkowski, M.; Modrzewska, B. Impact of traffic on the content of trace elements in soils along State Road 53 (Poland). Fresenius Environ. Bull. 2016, 25, 719-731.

2. Plyatsuk, L.D.; Chernysh, Y.Y.; Ablieieva, I.Y.; Yakhnenko, O.M.; Bataltsev, E.V.; Balintova, M.; Hurets, L.L. Remediation of soil contaminated with heavy metals. J. Eng. Sci. 2019, 6, H1-H8. [CrossRef]

3. Wyszkowski, M. Soil contamination with copper and its effect on selected soil properties after applying neutralizing substances. Pol. J. Environ. Stud. 2019, 28, 2465-2471. [CrossRef]

4. Bowszys, T.; Wierzbowska, J.; Bowszys, J. Content and removal of $\mathrm{Cu}$ and $\mathrm{Zn}$ with harvested crops grown on soil fertilized with composted municipal sewage sludge. J. Elem. 2009, 14, 23-32. [CrossRef]

5. Wołoszyk, C.; Iżewska, A.; Krzywy-Gawrońska, E. Content, uptake and utilization by plants of copper, manganese and zinc from municipal sewage sludge and wheat straw. J. Elem. 2009, 14, 593-604. [CrossRef] 
6. Elbagermi, M.A.; Edwards, H.G.M.; Alajtal, A.I. Monitoring of heavy metals content in soil collected from city centre and industrial areas of Misurata, Libya. Int. J. Anal. Chem. 2013, 2013, 312581. [CrossRef]

7. Żołnowski, A.; Busse, M.; Zajac, P. Response of maize (Zea mays L.) to soil contamination with copper depending on applied contamination neutralizing substances. J. Elem. 2013, 18, 507-520. [CrossRef]

8. Su, C.; Jiang, L.Q.; Zhang, W.J. A review on heavy metal contamination in the soil worldwide: Situation, impact and remediation techniques. Environ. Skep. Crit. 2014, 3, 24-38.

9. Pidlisnyuk, V.; Shapoval, P.; Zgorelec, Ž.; Stefanovska, T.; Zhukov, O. Multiyear phytoremediation and dynamic of foliar metal(loid)s concentration during application of Miscanthus $\times$ giganteus Greef et Deu to polluted soil from Bakar, Croatia. Environ. Sci. Pollut. Res. 2020, 27, 31446-31457. [CrossRef]

10. Rolka, E.; Żołnowski, A.C.; Kozłowska, K.A. Assessment of the content of trace elements in soils and roadside vegetation in the vicinity of some gasoline stations in Olsztyn (Poland). J. Elem. 2020, 25, 549-563.

11. Rolka, E.; Żołnowski, A.C.; Sadowska, M.M. Assessment of heavy metal content in soils adjacent to the DK16-route in Olsztyn (North-Eastern Poland). Pol. J. Environ. Stud. 2020, 29, 4303-4311. [CrossRef]

12. Alengebawy, A.; Abdelkhalek, S.T.; Qureshi, S.R.; Wang, M.Q. Heavy metals and pesticides toxicity in agricultural soil and plants: Ecological risks and human health implications. Toxics 2021, 9, 42. [CrossRef] [PubMed]

13. Panagos, P.; Van Liedekerke, M.; Yigini, Y.; Montanarella, L. Contaminated sites in Europe: Review of the current situation based on data collected through a european network. J. Environ. Public Health 2013, 2013, 158764. [CrossRef]

14. Borowik, A.; Wyszkowska, J.; Kucharski, J.; Baćmaga, M.; Boros-Lajszner, E.; Tomkiel, M. Sensitivity of soil enzymes to excessive zinc concentrations. J. Elem. 2014, 19, 637-648. [CrossRef]

15. Dopierała, U. Effect of copper and temperature on the growth and chlorophyll content of scentless mayweed (Tripleurospermum indorum (L.) Schultz-Bip.) Originated from vicinity of Glogow copper smelter. Ecol. Chem. Eng. A. 2009, 16, 739-743.

16. Zwolak, A.; Sarzyńska, M.; Szpyrka, E.; Stawarczyk, K. Sources of soil pollution by heavy metals and their accumulation in vegetables: A review. Water Air Soil Pollut. 2019, 230, 164. [CrossRef]

17. Kabata-Pendias, A. Trace Elements in Soils and Plants, 4th ed.; CRC Press Taylor \& Francis Group: Boca Raton, FL, USA, 2011; p. 505.

18. Kostecki, J.; Greinert, A.; Drab, M.; Wasylewicz, R.; Walczak, B. Chemical soil degradation in the area of the Głogów Copper Smelter Protective Forest. Civil Environ. Eng. Rep. 2015, 17, 61-71. [CrossRef]

19. Narendrula, R.; Nkongolo, K.K.; Beckett, P. Comparative soil metal analyses in Sudbury (Ontario, Canada) and Lubumbashi (Katanga, DR-Congo). Bull. Environ. Contam. Toxicol. 2012, 88, 187-192. [CrossRef]

20. Adress, M.; Ali, S.; Rizwan, M.; Ibrahim, M.; Abbas, F.; Farid, M.; Zia-ur-Rehman, M.; Irshad, M.K.; Bharwana, S.A. The effect of excess copper on growth and physiology of important food crops: A review. Environ. Sci. Pollut. Res. 2015, 22, 8148-8162. [CrossRef]

21. Komarek, M.; Cadkova, E.; Chrastny, V.; Bordas, F.; Bollinger, J.C. Contamination of vineyard soils with fungicides: A review of environmental and toxicological aspects. Environ. Int. 2010, 36, 138-151. [CrossRef] [PubMed]

22. Nazish, H.K.; Mohammad, N.; Farooq, A. Study of copper level in soil of selected orchard and non-orchard fields. Agri. Res. Tech. 2017, 9, 555764.

23. Komarek, M.; Vanek, A.; Chrastny, V.; Szakova, J.; Kubova, K.; Drahota, P.; Balik, P. Retention of copper originating from different fungicides in contrasting soil types. J. Hazard. Mater. 2009, 166, 1395-1402. [CrossRef] [PubMed]

24. Avramidis, P.; Barouchas, P.; Dünwald, T.; Unkel, I.; Panagiotaras, D. The influence of olive orchards copper-based fungicide use, in soils and sediments-The case of Aetoliko (Etoliko) Lagoon Western Greece. Geosciences 2019, 9, 267. [CrossRef]

25. Li, W.; Zhang, M.; Shu, H. Distribution and fractionation of copper in soils of apple orchards. Environ. Sci. Pollut. Res. 2005, 12, 168-172. [CrossRef] [PubMed]

26. Antoniadis, V.; Tsadilas, C.D.; Ashworth, D.J. Monometal and competitive adsorption of heavy metals by sewage sludge-amended soil. Chemosphere 2007, 68, 489-494. [CrossRef] [PubMed]

27. Rolka, E.; Wyszkowski, M. Availability of trace elements in soil with simulated cadmium, lead and zinc pollution. Minerals 2021, 11, 879. [CrossRef]

28. Wyszkowski, M.; Brodowska, M.S. Phytoextraction with maize of soil contaminated with copper after application of mineral and organic amendments. Agronomy 2020, 10, 1597. [CrossRef]

29. Inazumi, S.; Shishido, K.I.; Nontananandh, S.; Moriiwa, K. Remediation of heavy metals polluted soil using metal insolubilizing materials. J. Environ. Prot. 2018, 9, 770-789. [CrossRef]

30. Nwachukwu, O.I.; Pulford, I.D. Comparative effectiveness of selected adsorbant materials as potential amendments for the remediation of lead-, copper- and zinc-contaminated soil. Soil Use Manag. 2008, 24, 199-207. [CrossRef]

31. Żołnowski, A.C.; Ciećko, Z.; Najmowicz, T. Arsenic content in and uptake by plants from arsenic-contaminated soil. In Application of Phytotechnologies for Cleanup of Industrial, Agricultural, and Wastewater Contamination; Kulakow, P.A., Pidlisnyuk, V.V., Eds.; NATO Science for Peace and Security Series C: Environmental Security; Springer: Dordrecht, The Netherlands, 2010; pp. 135-145.

32. Karczewska, A.; Kabała, C. The soils polluted with heavy metals and arsenic in Lower Silesia-The need and methods of reclamation. Zesz. Nauk. UP Wroc. 2010, 576, 59-80. (In Polish)

33. Singh, S.; Parihar, P.; Singh, R.; Singh, V.P.; Prasad, S.M. Heavy metal tolerance in plants: Role of transcriptomics, proteomics, metabolomics, and ionomics. Front. Plant. Sci. 2016, 6, 1143. [CrossRef] 
34. Gao, X.; Hao, X.; Marchbank, D.H.; Beck, R.; Willms, W.D.; Zhao, M. Responses of herbage P, Ca, K and Mg content and Ca/P and $\mathrm{K} /(\mathrm{Ca}+\mathrm{Mg})$ ratios to long-term continuous and discontinued cattle grazing on a rough fescue grassland. Grass Forage Sci. 2016, 72, 581-589. [CrossRef]

35. Kumar, K.; Soni, A. Elemental ratio and their importance in feed and fodder. Int. J. Pure App. Biosci. 2014, 2, 154-160.

36. Grzegorczyk, S.; Alberski, J.; Olszewska, M. Accumulation of potassium, calcium and magnesium by selected species of grassland legumes and herbs. J. Elem. 2013, 18, 69-78. [CrossRef]

37. IUSS Working Group WRB. World Reference Base for Soil Resources 2014; World Soil Resources Report; International Soil Classification System for Naming Soils and Creating Legends for Soil Maps. World Soil Resources Reports No. 106; FAO: Rome, Italy, 2015. Available online: https:/ /www.fao.org/3/i3794en/I3794en.pdf (accessed on 18 August 2021).

38. Ostrowska, A.; Gawliński, S.; Szczubiałka, Z. Methods of Analysis and Assessment of Soil and Plants Properties; IOŚ: Warszawa, Poland, 1991; p. 331.

39. Ciećko, Z.; Mierzejewska, A.; Żołnowski, A.C.; Szostek, R. Influence of foliar nitrogen and magnesium fertilization on concentration of ash macronutrients in potato tubers. Ecol. Chem. Eng. A 2012, 19, 677-688.

40. Statistica, version 13; Data Analysis Software System; Tibco Software Inc.: Palo Alto, CA, USA, 2021. Available online: http: / / statistica.io (accessed on 18 August 2021).

41. Microsoft 2021; Microsoft ${ }^{\circledR}$ Excel $^{\circledR}$ for Microsoft 365 MSO. Microsoft Corp.: Albuquerque, NM, USA, 2021. Available online: http:/ / www.microsoft.com (accessed on 18 August 2021).

42. Cerovic, Z.G.; Masdoumier, G.; Ghozlen, N.B.; Latouche, G. A new optical leaf-clip meter for simultaneousnon-destructive assessment of leaf chlorophylland epidermal flavonoids. Physiol. Plant. 2012, 146, 251-260. [CrossRef] [PubMed]

43. Gabriel, J.L.; Quemada, M.; Alonso-Ayuso, M.; Lizaso, J.I.; Martín-Lammerding, D. Predicting N status in maize with clip sensors: Choosing sensor, leaf sampling point, and timing. Sensors 2019, 19, 3881. [CrossRef]

44. Zhang, K.; Liu, X.; Ma, Y.; Zhang, R.; Cao, Q.; Zhu, Y.; Cao, W.; Tian, Y. A comparative assessment of measures of leaf nitrogen in rice using two leaf-clip meters. Sensors 2020, 20, 175. [CrossRef]

45. Feil, S.B.; Pii, Y.; Valentinuzzi, F.; Tiziani, R.; Mimmo, T.; Cesco, C. Copper toxicity affects phosphorus uptake mechanisms at molecular and physiological levels in Cucumis satious plants. Plant. Physiol. Biochem. 2020, 157, 138-147. [CrossRef]

46. Pichnode, M.; Nikhil, M. Effect of copper dust on photosynthesis pigments concentration in plants species. Int. J. Eng. Res. Manag. 2015, 2, 63-66.

47. Asati, A.; Pichnode, M.; Nikhil, M. Effect of Heavy Metals on Plants: An Overview. Int. J. Appl. Innov. Eng. Manag. 2016, 5, 56-66.

48. Pishchik, V.N.; Vorob'ev, N.I.; Provorovb, N.A.; Khomyakov, Y.V. Mechanisms of plant and microbial adaptation to heavy metals in plant-microbial systems. Microbiology 2016, 85, 257-271. [CrossRef]

49. Xu, J.K.; Yang, L.X.; Wang, Z.Q.; Dong, G.C.; Huang, J.Y.; Wang, Y.L. Effects of soil copper concentration on growth, development and yield formation of rice (Oryza sativa). Rice Sci. 2005, 12, 125-132.

50. Derakhshan Nejad, Z.; Myung, N.; Jung, C.; Kim, K.H. Remediation of soils contaminated with heavy metals with an emphasis on immobilization technology. Environ. Geochem. Health 2018, 40, 927-953. [CrossRef]

51. Szatanik-Kloc, A. Changes in surface properties of plant roots determined by aluminium and copper phytotoxicity. Acta Agroph. 2010, 176, 122 .

52. Korzeniowska, J.; Stanisławska-Glubiak, E. Phytoremediation potential of Phalaris arundinacea, Salix viminalisand, Zea mays for nickel-contaminated soils. Int. J. Environ. Sci. Tech. 2019, 16, 1999-2008. [CrossRef]

53. Pedersen, M.B.; Kjær, C.; Elmegaard, N. Toxicity and bioaccumulation of copper to black bindweed (Fallopia convolvulus) in relation to bioavailability and the age of soil contamination. Arch. Environ. Contamin. Toxicol. 2000, 39, 431-439. [CrossRef] [PubMed]

54. Amin, H.; Arain, B.A.; Jahangir, T.M.; Abbasi, A.R.; Mangi, J.; Abbasi, M.S.; Amin, F. Copper (Cu) tolerance and accumulation potential in four native plant species: A comparative study for effective phytoextraction technique. Geol. Ecol. Landsc. 2021, 5, 53-64. [CrossRef]

55. Meychik, N.; Nikolaeva, Y.; Kushunina, M. The role of the cell walls in Ni binding by plant roots. J. Plant. Physiol. 2019, 234-235, 28-35. [CrossRef] [PubMed]

56. Zhou, X.; Huang, G.; Liang, D.; Liu, Y.; Yao, S.; Ali, U.; Hu, H. Influence of nitrogen forms and application rates on the phytoextraction of copper by castor bean (Ricinus communis L.). Environ. Sci. Pollut. Res. 2020, 27, 647-656. [CrossRef]

57. Rascio, N.; Navari-Izzo, F. Heavy metal hyperaccumulating plants: How and why do they do it? And what makes them so interesting? Plant. Sci. 2011, 180, 169-181. [CrossRef]

58. Van Der Ent, A.; Baker, A.J.M.; Reeves, R.D.; Pollard, A.J.; Schat, H. Hyperaccumulators of metal and metalloid trace elements: Facts and fiction. Plant. Soil 2012, 362, 319-334. [CrossRef]

59. Kuziemska, B.; Kalembasa, S.; Jakubicka, M. Effect of application of lime and sewage sludge addition on the content of iron, copper and zinc in Dactylis glomerata L. cultivated on nickel contaminated soil. J. Ecol. Eng. 2011, 27, $92-99$.

60. Farzadfar, S.; Zarinkamar, F.; Modarres-Sanavy, S.A.M.; Hojati, M. Exogenously applied calcium alleviates cadmium toxicity in Matricaria chamomilla L. Plants. Environ. Sci. Pollut. Res. 2013, 20, 1413-1422. [CrossRef] [PubMed]

61. Antoniadis, V.; Damalidis, K. Copper availability in an acidic and limed zeolite-amended soil. Commun. Soil Sci. Plant. Anal. 2014, 45, 881-886. [CrossRef] 
62. Rietra, R.P.J.J.; Heinen, M.; Dimkpa, C.O.; Bindraban, P.S. Effects of nutrient antagonism and synergism on yield and fertilizer use efficiency. Commun. Soil Sci. Plant. Anal. 2017, 48, 1895-1920. [CrossRef]

63. Kuziemska, B.; Trębicka, J.; Wysokiński, A. Uptake and utilization of nitrogen from organic fertilizers influenced by different doses of copper. Agronomy 2021, 11, 1219. [CrossRef]

64. Snowball, K.; Robson, A.D.; Loneragan, J.F. The effect of copper on nitrogen fixation in subterranean clover (Trifolium subterraneum). New Phytol. 1980, 85, 63-72. [CrossRef]

65. Alhasany, A.; Noaema, A.H.; Alhmadi, H.B. The role of spraying copper and zinc on the growth and yield of Vicia faba L. IOP Conf. Ser. Mater. Sci. Eng. 2019, 571, 012048. [CrossRef]

66. Meller, E.; Jarnuszewski, G. Chemical composition of plants grown on post-bog soils fertilised with zinc and copper. Zesz. Nauk. UZ Inż. Środ. 2015, 159, 45-53. (In Polish)

67. Alaouis-Sosse, B.; Genet, P.; Vinit-Dunand, F.; Toussaint, M.; Epron, D.; Badot, P. Effect of copper on growth in cucumber plants (Cucumis sativus) and its relationships with carbohydrate accumulation and changes in ion contents. Plant. Sci. 2004, 166, 1213-1218. [CrossRef]

68. Grzegorczyk, S.; Grabowski, K. The K:(Ca+Mg) Ratio in meadow sward irrigated with wastewater. J. Elem. 2019, 4, 953-959. [CrossRef]

69. Grzegorczyk, S.; Alberski, J.; Olszewska, M.; Grabowski, K.; Bałuch-Małecka, A. Content of calcium and phosphorus and the $\mathrm{Ca}$ :P ratio is selected species of leguminous and herbaceous plants. J. Elem. 2017, 22, 663-669. [CrossRef]

70. Jarnuszewski, G.; Meller, E. Mineral element ratios in plants grown on post-bog soils fertilised with zinc and copper. Folia Pomer. Univ. Technol. Stetin. Agric. Aliment. Pisc. Zootech. 2013, 304, 25-32. (In Polish) 